\title{
Reducing Furrow Irrigation Erosion with Polyacrylamide (PAM)
}

\author{
R. E. Sojka and R. D. Lentz
}

Research Question

\section{Literature Summary}

There has been a large shift to sprinkler irrigation in the USA. Beyond labor considerations, this has been driven by soil and water resource conservation. Some crops, however, do not tolerate wet canopies (e.g., seed beans). Furthermore, the capital cost, energy use, and technological requirements are out of the reach of many U.S. and third world irrigators. If inexpensive, effective, easy erosion control were available, many furrow irrigation farmers could improve resource conservation and water management.

Small amounts of a specific class of polyacrylamide (PAM) copolymer can virtually halt furrow irrigation-induced erosion. Net infiltration is also improved (infiltration rate does not decline, compared with untreated water) while management options are broadened. Various copolymer formulations of water-soluble PAM and other copolymers have been available for soil-stabilization in agriculture since the 1950s. While these conditioners were effective at stabilizing soil structure and improving infiltration, early materials and high application rates were prohibitively expensive for all but high-return uses.

In 1991, work by the USDA's Agricultural Research Service in Kimberly, ID, demonstrated that $1 \mathrm{lb} /$ acre of moderate molecular weight (12-15 Mg/mole) anionic polyacrylamide water soluble copolymer could virtually halt furrow irrigation-induced erosion. Treatment required dissolving PAM at a concentration of $10 \mathrm{ppm}$ in the irrigation water during its initial traverse down the dry furrow (advance). The treatment has proven consistently effective for a variety of soils and textures on freshly tilled furrows having slopes of as much as $7 \%$. Net infiltration rates are also improved, with increases ranging from $15 \%$ in silt loam soils to $50 \%$ in clayey soils.

Extensive testing in Idaho, complemented by studies in several other westem states, led in 1994 to commercial product registration in most western states. In January 1995, the Natural Resources Conservation Service (NRCS) published a western states interim conservation practice standard to describe preferred methodology. Practice adoption in 1995 was estimated at 50000 acres in the USA, predominantly the Pacific Northwest. A number of locales now have cost sharing for the practice.

There is intense user interest in implementation and further development of this approach. Emphasis of recent research and farmer inquiries has been focused on development of easy application technology, minimization of PAM requirement, and verification of PAM's inherent resistance to off-field migration. 


\section{Applied Questions}

\section{Recommendation}

There are several effective ways to apply PAM. The NRCS standard calls for dissolving PAM in irrigation water, bringing the concentration to $10 \mathrm{ppm}$ in the flow during water advance, and then halting PAM addition when runoff begins. Add PAM to the water slowly (never add water to PAM). Provide adequate turbulence in the flow to insure thorough mixing. Direct application of PAM at the furrow head, or use of large PAM blocks in the head ditch is being evaluated.

\section{Are there special needs for best results?}

With PAM, high sediments suspended in supply water may settle out almost immediately, deactivating some PAM. A small settling pond at the top of the field can prevent sediment from filling head ditches. Using larger siphon tubes prevents sediment from adhering to the inside of the tubes and increases initial inflow rates.

Farmers should increase initial inflow rates (double or more) with PAM. Higher inflows will not cause erosion if PAM is in the flow, and will compensate for higher infiltration rates with PAM and shorten the advance time. Once runoff begins, cutting back to the minimum sustainable flow rate optimizes this practice.

The first water reaching the furrow must contain 10 ppm PAM or else PAM effectiveness will be greatly diminished. Similarly, PAM effectiveness is less when surface soil is moist. Occasionally farmers irrigate when the soil profile is still somewhat wet, for example, after a rain shower. Irrigation is done to "stay on schedule" because water deliveries to several fields takes a number of days. If erosion or infiltration is an overriding concern, the best strategy, if at all possible, is to wait until the soil has dried enough to increase infiltration and PAM absorption.

Farmers should buy only registered (labeled) PAM. There is little chance that familiar major agrichemical suppliers, will supply the wrong formulations. Crosslinked superabsorbent or gel-forming PAMs will not halt erosion. Cationic formulations can be toxic.

PAM is an effective and inexpensive way to prevent furrow irrigation-induced soil erosion. It should not preclude the use of other reliable conservation practices. But where these practices are not possible, or where farmers have resisted implementing other practices, PAM may provide a conservation option that meets their needs. Use of PAM should follow the NRCS practice standard, which recommends $10 \mathrm{ppm}$ in the inflow during the advance phase (only) of furrow irrigation sets for those irrigations when the soil in the furrow is loose (e.g., after furrow forming or cultivation). Use of PAM during additional irrigations can be beneficial, but farmers should determine if full rate application is required for adequate control on their fields in these cases. 


\title{
Reducing Furrow Irrigation Erosion with Polyacrylamide (PAM)
}

\author{
R. E. Sojka* and R. D. Lentz
}

Irrigated cropping is a critical component of global agricultural production. Surface irrigation-most of it furrow irrigation-accounts for $>60 \%$ of Earth's 600 million irrigated acres. Erosion threatens irrigation's ability to maintain its $2 X$ average yield advantage and $3 X$ value over rainfed agriculture, with serious environmental and food security consequences to the burgeoning human population. Furrow irrigation-induced erosion is nearly halted by small additions of water-soluble polyacrylamide (PAM) to irrigation water. PAM is an environmentally safe focculent used extensively in municipal water treatment, paper manufacturing, food processing, and other sensitive applications. On freshly cultivated furrows, $1 \mathrm{lb} /$ acre of PAM applied at $10 \mathrm{ppm}$ in irrigation water before runoff began (only), reduced sediment loss in runoff $94 \%$ and increased net water infiltration $15 \%$ in $3 \mathrm{yr}$ of Idaho tests on silt loam soils. Irrigation return-flow quality was improved by PAM-use, greatly reducing sediment losses, biochemical oxygen demand (BOD), total $P$, and various pesticides. Polyacrylamide products are now registered in most western states and the Natural Resources Conservation Service (NRCS) has published a PAM-use practice standard. Cost sharing is available in some locales. In 1995 about 50000 acres of furrow-irrigated land used PAM, halting as much as 1 million tons of soil erosion in the first year. Farmers see PAM-use as an attractive alternative to more difficult conservation practices. The typically $\$ 15$ to $\$ 35 /$ acre per crop costs are partially or entirely retrieved by crop responses or savings in erosion-related field operations and water conservation. Pam-use in irrigation is expected to expand rapidly in 1996.

\section{$\mathrm{P}$} OLYACRYLAMIDE use in furrow irrigation water is one of the fastest growing soil and water conservation technologies in irrigated agriculture. Polyacrylamides were registered in most western states by the end of 1994, and an interim conservation practice standard for PAM-use was published in January 1995 (Anon., 1995). About 50000 acres were PAM-treated in 1995, its first year of commercial use for irrigation-induced erosion control, saving as much as 1 million tons of soil (Sojka and Lentz, 1996a). To understand PAM's appeal to irrigators, one must understand irri-

USDA-ARS Northwest Irrig. and Soils Res. Lab, 3793N-3600E Kimberly, ID 83341 . Received 8 Apr. 1996. *Corresponding author (sojka@kimberly.ars.pn.usbr.gov; fax 208/423-6555).

Published in J. Prod. Agric. 10:47-52 (1997). gated agriculture's value, soil erosion's threat to that value, and this new technology's potential to conserve soil for furrow irrigators, who have resisted implementing more difficult conservation approaches.

\section{IMPORTANCE OF THE IRRIGATED RESOURCE}

About 600 million of Earth's 3.2 billion acres of crop land $(15-17 \%)$ are irrigated, mostly surface irrigated (Hoffman et al., 1990, Gleick, 1993). In the USA, about 32 of 60 million irrigated acres are surface irrigated, mostly with furrows (Anon., 1996).

Most irrigation occurs in arid or semi-arid climates (Bucks et al., 1990) which generally allow higher photosynthetic rates (less cloudiness), while lower disease, insect, and weed pressures minimize fungicide, herbicide, and pesticide inputs. Arid soils seldom require $\mathrm{K}$ fertilizers or lime, even with ammoniacal fertilizers. Their low organic matter contents and high $\mathrm{pH}$ reduce required rates of soil incorporated herbicides (Ross and Lembi, 1985).

Because water, nutrient availability, and pest control are more easily optimized, irrigated commodities generally have higher quality than rain-fed. Average irrigated yields are double rain-fed yields and account for $1 / 3$ of all crop yield, and about half the value of all crops grown (Rangeley, 1987; Bucks et al., 1990). About 125 million acres of Earth's best irrigated crop land ( $4 \%$ of total cropland) produces $1 / 3$ of her entire food crop (Tribe, 1994).

\section{FURROW IRRIGATION EROSION'S THREAT TO THE RESOURCE}

The arid and semi-arid soils supporting most of the world's irrigation have thin, easily erodible topsoil. Furrow irrigation is inherently erosive. Runoff typically carries away 20 tons of soil per acre per year in the US Pacific Northwest, with three to eight times that amount of erosion occurring near the upper ends of fields near furrow inlets (Carter, 1993; Trout, 1996). The high productivity of irrigated agriculture, the high erodibility of shallow arid topsoils, and the inherent erosiveness of furrow irrigation converge to define a critical problem. Lost sustainability of irrigated agriculture would devastate our ability to feed and

Abbreviations: BOD, biochemical oxygen demand; NRCS, Natural Resources Conservation Service; PAM, polyacrylamide. 
Table 1. Percent maximum yield on Portneuf soil having the entire $A$ horizon removed (from Carter, 1993).

\begin{tabular}{lc}
\hline Cropt & Percentage maximum yield without the A Horizon \\
\hline Wheat & 51 \\
Sweet com & 52 \\
Alfalfa & 67 \\
Dry bean & 60 \\
Barley & 68 \\
Sugarbeet & 79 \\
\hline
\end{tabular}

† Wheat, Triticum aestivum L.; sweetcom, Zea mays L.; alfalfa, Medicago sativa L.; dry bean, Phaseolus vulgaris L.; barley, Hordeum vulgare L.; sugarbeet, Beta vulgaris $\mathrm{L}$.

clothe Earth's burgeoning population (Table 1). Over 1.2 billion acres of existing grasslands, rain forests, or wetlands would be needed to replace the output of irrigated agriculture if the resource were lost.

Many conservation practices for furrow irrigation were developed in the last $25 \mathrm{yr}$ (Sojka, 1997); several eliminate $80 \%$ or more of the sediment in irrigation runoff. Yet, few practices have wide acceptance, even after decades of demonstration and promotion. This is because residue placement, reduced tillage, etc. are regarded as cumbersome and intrusive by furrow irrigators, who prefer smooth unobstructed furrows to convey water efficiently.

Traditional soil conservation practices that reduce runoffsediment by 60 to $70 \%$ still lose about two thirds of the claysized fraction (Brown et al., 1981). These solids, with their higher surface areas, are the most important soil components for sustained soil fertility. They also are most responsible for $\mathrm{BOD}$, pesticide, and eutrophying nutrient problems in return-flow receiving waters.

\section{PAM'S CONSERVATION BENEFITS}

Dissolved at $10 \mathrm{ppm}$ in advancing furrow irrigation water, PAM provides effective soil conservation with furrow irrigation (Fig. 1), without the kind of problems that discourage many farmers from using other soil conservation approaches (Lentz et al., 1992; Lentz and Sojka, 1994; Sojka and Lentz, 1994a; Lentz, 1995). Used according to the NRCS practice standard (Anon., 1995), 94\% of runoff-sediments are retained on fields, even conventional clean-tilled fields, using no other conservation practices (Lentz and Sojka, 1994). PAM is a potent flocculent; thus it retains nearly all clay-sized material.

Used according to the NRCS standard, PAM increased infiltration $15 \%$ on silt loam soils in Idaho (Lentz et al., 1992; Trout et al., 1993; Lentz and Sojka, 1994; Trout et al., 1995 ) and about $50 \%$ on finer textured soils (McCutchan et al., 1994). Polyacrylamide can increase initial infiltration rates in swelling soils but may not always effect total infiltration where intake is eventually limited by swelling and subsurface pore blockage (Mitchell, 1986). Because PAMtreated furrows did not erode deeper channels, their infiltrated water moved $25 \%$ further laterally in 4 -in. $(10-\mathrm{cm})$ deep furrows between level beds in Idaho tests (Lentz et al., 1992). Thus, PAM-use can also save water, especially in early irrigations when only enough water is needed to reach seeds or seedlings.

\section{HOW PAM WORKS IN IRRIGATION WATER}

Water-applied erosion-preventing PAMs are large, negatively charged molecules. These PAMs are high molecular

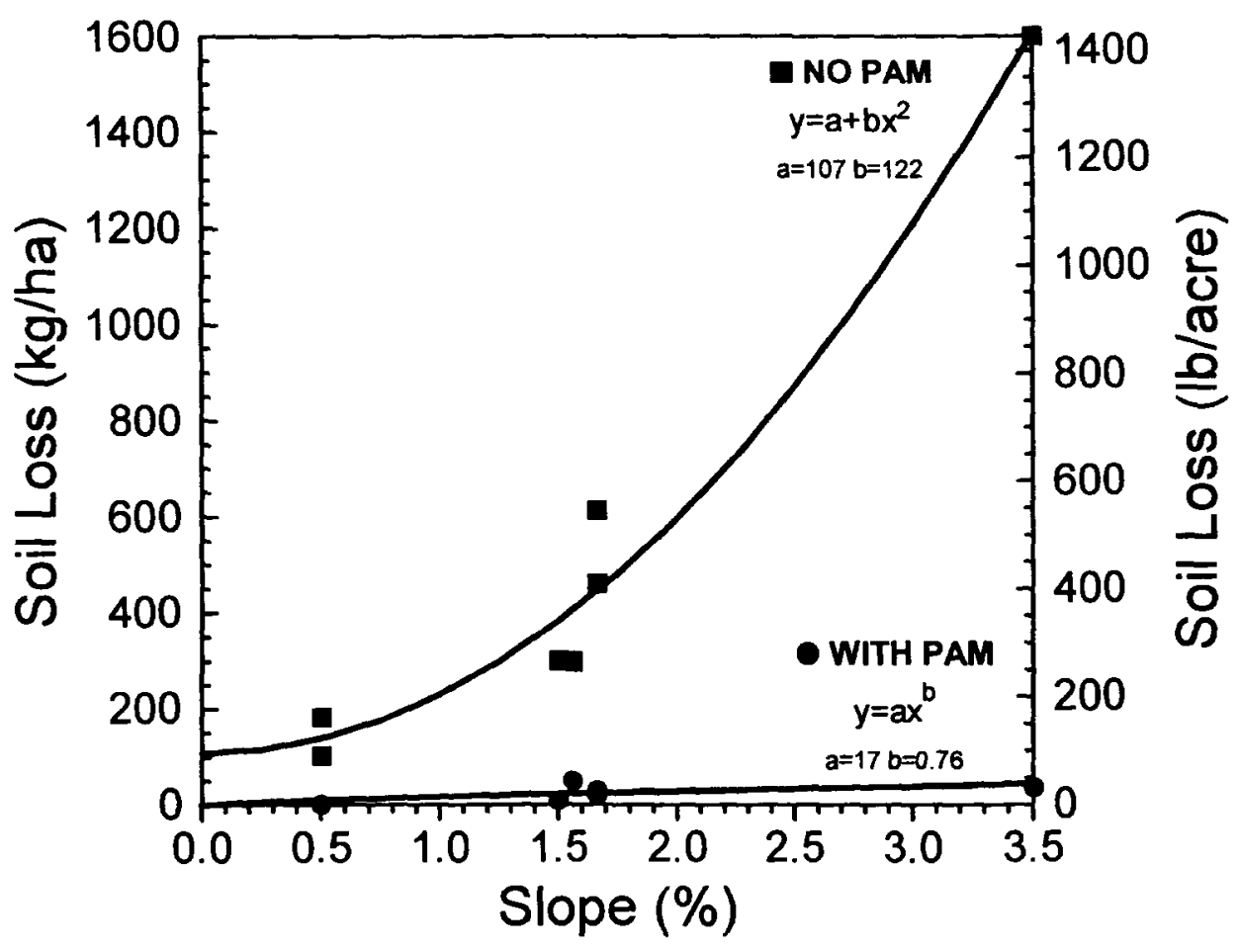

Fig. 1. Soil loss curves as a function of slope, derived from 12-hour irrigations on similar silt loam soils in southern Idaho. Curves are best fit of selected data. Data was selected from numerous unrelated studies with minor differences in protocol, requiring some judgement. Regression analysis was used for drawing the curves but may not provide strictly reliable estimation of variability. 
weight polymers, about $15 \mathrm{Mg} /$ mole, or about 150000 monomer units per molecule. They are moderately anionic, typically $18 \%$ negative charge density, and contain less than $0.05 \%$ residual acrylamide monomer by weight. The negative charge results when one in five amide functional groups is converted to sodium formate. The sodium cation dissociates in water, leaving a negative charge on the polymer for each cation dissociated. Divalent cations in water act as a bridge between the PAM and soil particles, increasing soil cohesion and strengthening aggregates in the furrow (De Boodt et al., 1990; Barvenik, 1994, Sojka and Lentz, 1994b). Soil particles at the furrow's soil-water interface are bound more securely. This greatly reduces detachment and transport of sediments in runoff. Soil erodibility is reduced by improved interaggregate bonding and by better maintenance of surface roughness.

Because PAM only treats the wetted perimeter of furrows, and since PAM penetrates soil only a few millimeters (Malik et al. 1991), very small net application rates are effective, typically $1 \mathrm{lb}$ /acre (Fig. 2). These, however, are the few millimeters most critical to the erosion process.

Polyacrylamide is also a settling agent. When PAM is present in water, it flocculates clay and silt particles dispersed by and carried in the flow, enabling them to settle to the furrow bottom. Because dispersed fines are absent from the infiltrating water, pores remain open and infiltration rates are higher than for sediment-laden water. Maintenance of pore structure has been demonstrated in treated furrows by higher infiltration rates under tension compared with controls (Ross et al., 1996, Sojka et al., 1996). Higher net infiltration decreases runoff rate and amount, further reducing stream force, carrying capacity, and transport volume.

\section{DESCRIPTION OF THE PRACTICE}

There are several effective ways to apply PAM, depending on the form of PAM used and the furrow irrigation system employed. Using PAMs to halt furrow erosion is accomplished most often as follows (Anon., 1995). Farmers must purchase one of several registered polyacrylamide copolymer products. They should check product labels to ensure that the PAM copolymer they purchase has the properties described in the previous section.

\section{PAM-Treated Furrow Irrigation}

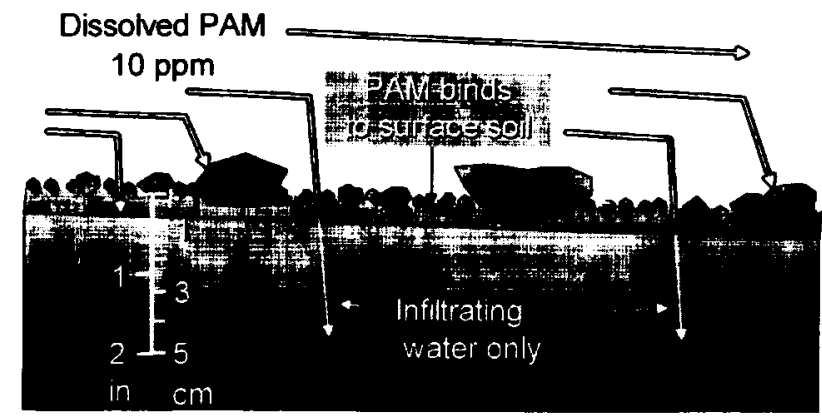

Fig. 2. Schematic showing the entry of water into pores at the soil water interface of irrigation furrows, carrying polyacrylamide copolymer (PAM). The PAM coats and stabilizes the thin layer of soil at the soil interface as water infiltrates, bringing PAM in contact with it.
If purchased from familiar major agrichemical suppliers, there is little chance of obtaining improper formulations. Crosslinked superabsorbent or gel-forming PAMs are not water soluble and will not be effective. Cationic formulations can be toxic to aquatic environments and should not be used. Major suppliers will provide high potency materials (usually $80-90 \%$ active material, typically costing $\$ 4.50-\$ 5.50 / \mathrm{lb}$ in granular form). Repackagers may add inert materials to dilute the PAM, which looks like table sugar. At least one major supplier provides field technical support to help farmers learn how to use PAM. A variety of inexpensive, automated head-ditch applicators is available for predissolved PAM stock solutions, high concentration emulsions and granular products.

These water-soluble PAMs are dissolved into irrigation supply ditches, either as concentrated stock solutions, high concentrate emulsions, suspended bulk blocks, or as dry granules. If dry granules are metered into the flow, one must add the PAM to the flow slowly and provide enough mixing in the ditch to promote uniform PAM dissolution and distribution (water should never be added to PAM). Uniform dissolution is often accomplished by placing dams in ditches immediately downstream of the PAM applicator. Turbulence at the over-falls does the mixing. Enough PAM is metered into the flow to bring ditch water to $10 \mathrm{ppm}$ (Lentz et al., 1995). The 10-ppm PAM water is added to dry furrows at inflow rates sufficient to rapidly advance water across the field. Farmers have also begun to treat furrows by scattering small patches of PAM granules or placing small PAM cubes at the head of individual furrows (Sojka and Lentz, 1996b). Research is also underway looking at delivery of PAM concentrates to individual furrows via drip lines. Special considerations for PAM-use have been outlined in several publications (Sojka and Lentz, 1996a,c; Lentz et al., 1995).

It is important that no untreated water wet the furrow ahead of the PAM-treated flow. Untreated water destroys soil structure before PAM can stabilize it, greatly reducing PAM's effect. Wet furrows also reduce infiltration through the soil-water interface, thereby delivering less PAM to the thin target layer of soil at the furrow bottom. This reduced application efficiency may both increase PAM costs and the risk of PAM loss off-site.

If there is a significant amount of sediment suspended in the water supply, PAM will cause it to flocculate and settle out almost immediately. A small settling pond at the top of the field may be necessary to prevent sediment from filling head ditches. It is advisable to use larger siphon tubes to prevent sediment from adhering to the inside of the tubes and to increase initial inflow rates. If source-water sediment load is exceedingly high, greater than about $0.75 \mathrm{oz} / \mathrm{gal}(5 \mathrm{~g} / \mathrm{L})$, a slight increase in PAM application rate may be necessary to compensate for PAM-deactivation from flocculation.

When applying PAM-treated water to furrows, a higher than normal inflow rate should be used (double or more). This is both to overcome the increased infiltration rate associated with PAM-use and to improve infiltration uniformity between upper and lower field reaches. Work in Idaho (Sojka et al., 1995) showed that PAM-treated inflows increased advance time by about one third if inflow rates with PAM were not adjusted. Doubling PAM-treated inflow rates 
Table 2. Season average total sediment loss (pounds per acre per irrigation) from a 1994 potato (Solanum tuberosum L.) study in which PAM was used according to the NRCS practice standard early in the season. PAM treatment was halted as vines began to form a complete canopy.

\begin{tabular}{|c|c|c|c|c|}
\hline \multirow[b]{2}{*}{ Inflow rate } & \multicolumn{2}{|c|}{$\begin{array}{c}\text { Early season } \\
\text { PAM-treated irrigations }\end{array}$} & \multicolumn{2}{|c|}{$\begin{array}{l}\text { Late season } \\
\text { untreated irrigations }\end{array}$} \\
\hline & Control & PAM applied & Control & Residual PAM \\
\hline & \multicolumn{4}{|c|}{ Sediment loss, lb/acre } \\
\hline Normal & 279.0 & 32.8 & 26.2 & 4.7 \\
\hline High & 743.1 & 70.0 & 60.9 & 8.5 \\
\hline
\end{tabular}

compared with controls reduced advance time by $19 \%$ with a $74 \%$ sediment reduction in runoff compared with controls (Table 2).

When water is about to run off the end of the furrow, addition of PAM to the head ditch is stopped. Untreated water is used for the balance of the irrigation period. The advance period usually consists of the first quarter to one third of a furrow irrigation set, which is typically either 12 or $24 \mathrm{~h}$. When water begins to run off, it is recommended that furrow inflows be reduced to the lowest flow needed to sustain a minimal runoff rate. In $5 \mathrm{yr}$ of testing in Idaho, this application method has required about $1 \mathrm{lb}$ of PAM/treatment per acre, or $1 \mathrm{lb}$ of PAM/acre-inch of total irrigation inflow (Lentz and Sojka, 1994, Lentz and Sojka, 1996).

Erosion protection declines about $50 \%$ if furrows are undisturbed after a treated irrigation, and subsequently are irrigated with untreated water (Lentz et al., 1992). Furrows disturbed by traffic or cultivation must be retreated again at the $10 \mathrm{ppm}$ PAM rate during inflow advance. Furrows typically become less erosive late in the season (Brown et al., 1995). Canopy vegetation and residue often intrudes into furrow bottoms late in the season, reducing the erosion potential. When crop canopies shade PAM-treated furrows, Ultraviolet light deterioration of PAM and physical destruction of polymer bonds caused by shrinking of soil during drying is also reduced. The number of irrigations needing treatment varies with crop, cultural practices, and growing season length. Season-long application requirements are typically three to seven irrigations at a $1 \mathrm{lb}$ PAM/acre for $94 \%$ erosion reduction. This implies applying PAM in the first irrigation and in every irrigation after which the soil has been disturbed by cultivation, furrow reshaping or other traffic in the furrow.

\section{ECONOMIC AND ENVIRONMENTAL ASPECTS OF PAM-USE}

Polyacrylamide products are commercially available for $\$ 4$ to $\$ 5.50 / \mathrm{lb}$. Various PAM head-ditch applicators are available, typically costing a few hundred dollars each. Use of PAM is inexpensive enough to be attractive to many farmers who perceive an erosion problem, regardless of other economic considerations. Often, however, costs are offset by elimination of sediment retention basins or reduced basin maintenance. Furrow reshaping (cultivation), a $\$ 4$ to $8 /$ acre expense, is often eliminated because uneroded channels function well long into the season.

Also, halting erosion prevents exposure in furrow bottoms of soil not treated with herbicides, thus reducing poten- tial late-season weed problems. Soil-applied pesticides and fertilizers are retained on the field, and not transferred by erosion and return flows to receiving waters or riparian areas. With virtually no soil entrained in runoff, return flows contain few dissolved organics and nutrients (Agassi et al., 1995; Singh et al., 1996; Bahr and Steiber, 1996; Lentz and Sojka, 1994).

Improved infiltration amount and uniformity can also increase crop yield and quality in some cases. If PAM is used to nonerosively increase inflows and reduce advance times, more uniform infiltration from upper field ends to lower field ends can improve potato (Solanum tuberosum L.) yield and grade (Sojka et al., 1995). This same practice is expected to reduce the risk of nitrate leaching from overirrigation of the upper field reaches.

Affordable rates of registered PAMs applied to soil do not impair uptake of nutrients and sometimes improve nutrition indirectly through improved aggregation (Quastel, 1954). Even at rates as high as $1 \%(20$ tons/acre) the yield of wheat (Triticum aestivum L.) and tomatoes [Lycopersicon lysopersicum (L.) Karsten var. lycopersivum] was improved, with small decreases in some nutrient concentrations explainable (Wallace et al., 1986), possibly due to uptake dilution. In a related study (Wallace, 1986), tomato yields increased when grown in solution culture at $\mathrm{pH} 4.5$ or 7.5 with $100 \mathrm{ppm}$ of an anionic PAM; there were only small changes in nutrient status, which probably resulted from uptake dilution or chelation of some nutrients in solution (a phenomenon that probably would be blocked by PAM adsorption to soil).

One concern often voiced regarding PAM-use is whether environmental or health threats exist from residual acrylamide monomer (a toxin) left behind from product synthesis, or as the result of PAM degradation. Products labeled for sale in the USA as erosion polymers are formulated to the same EPA and FDA standards as those used in potable water treatment and for food processing and packaging uses. They are large anionic PAM copolymers that are both environmentally safe and among the most efficacious formulations for this use (Lentz et al., 1993). By U.S. law, they may contain no more than $0.05 \%$ monomer. Free monomer is readily metabolized in biologically active environments, with a half life of hours; furthermore, PAM does not decompose to release free monomer (Barvenik, 1994). Analysis of tissue from dry beans (Phaseolus vulgaris), sugarbeet (Beta vulgaris L.), and corn (Zea mays L.) grown in Kimberly, ID, in soil treated in 1995 with $1000 \mathrm{lb} / \mathrm{acre}$ found no detectable acrylamide monomer in harvested plant materials (Barvenik et al., 1996). No negative impacts have been documented on soil microflora from fields with several years of exposure to polyacrylamide for erosion control (Watwood and KayShoemake, 1996).

\section{CONCLUSIONS}

Use of PAM for erosion control is a potent tool for helping guarantee sustainability of irrigated agriculture. It provides a potent environmental benefit. It has been shown to effectively halt furrow irrigation erosion on a variety of western soils (Sojka and Lentz, 1996c), about half a ton of soil per ounce of PAM used in Idaho tests. It removes sub- 
stantial amounts of sediment, $P$, and pesticides from return flows, and greatly reduces return-flow BOD. It increases infiltration and improves lateral wetting, which can facilitate conservation of water, the West's scarcest natural resource. Reduced sediment and nutrient loading of riparian resources will curtail algal blooms, reduce turbidity and sedimentation of stream bottoms, decelerate reservoir in-filling, and reduce abrasion of hydropower machinery. Use of PAM allows changes in furrow management that should provide more uniform water application and reduce Nitrate- $\mathrm{N}$ leaching.

While detailed cost analyses are not yet available, PAMuse will reduce furrow reshaping and sediment pond or ditch cleaning. Thus it will conserve fuel, lessen air pollution, reduce equipment wear and labor, and allow crop production on land once occupied by sediment ponds or in field areas where slopes hindered intake as furrows cut narrow deep channels, reducing the wetted perimeter.

Perhaps most importantly, furrow irrigation farmers who have seen demonstrations of this new practice are enthusiastic about it. It is regarded as a highly effective conservation option without the drawback to furrow irrigators of some traditional conservation practices. Farmer enthusiasm for the practice raises its potential for implementation and, hence, conservation and nonpoint source pollution-reduction.

\section{ACKNOWLEDGMENT}

The Authors wish to thank technicians Jim Foerster and Ron Peckenpaugh for their diligence and dedication to this project for the past $5 \mathrm{yr}$. Their hard work has made possible a much earlier transfer to irrigation farmers of usable and highly effective conservation technology.

\section{REFERENCES}

Agassi, M., J. Letey, W.J. Farmer, and P. Clark. 1995. Soil erosion contribution to pesticide transport by furrow irrigation. J. Environ. Qual. 24:892-895.

Anonymous. 1995. Interim conservation practice standard-Irrigation erosion control (polyacrylamide). WNTC 201-1. NRCS West Natl. Tech. Cent., Portland, OR.

Anonymous. 1996. 1995 Irrigation survey reflects steady growth. Irrig. J. 46:24-39.

Bahr, G., and T. Steiber. 1996. Reduction of nutrient and pesticide loss through the application of polyacrylamide in surface irrigated crops. p. 41-48. In R.E. Sojka and R.D. Lentz (ed.) Proc. Conf. on Managing Irrigation-Induced Erosion and Infiltration with Polyacrylamide, Twin Falls, ID. 6-8 May 1996. Univ. of Idaho, Moscow.

Barvenik, F.W. 1994. Polyacrylamide characteristics related to soil applications. Soil Sci. 158:235-243.

Barvenik, F.W., R.E. Sojka, R.D. Lentz, F.F. Andrawes, and L.S. Messner. 1996. Fate of acrylamide monomer following application of poly-acrylamide to cropland. p. 103-110. In R.E. Sojka and R.D. Lentz (ed.) Proc. Conf. on Managing irrigation-induced erosion and infiltration with polyacrylamide, Twin Falls, ID. 6-8 May. Univ. of Idaho, Moscow.

Brown, M.J., J.A. Bondurant, and C.E. Brockway. 1981. Ponding surface drainage water for sediment and phosphorous removal. Trans. ASAE. 24:1478-1481.

Brown, M.J., D.L. Carter, G.A. Lehrsch, and R.E. Sojka, 1995. Seasonal trends in furrow irrigation erosion in southem Idaho. Soil Technol. 8:119-126.

Bucks, D.A., T.W. Sammis, and G.L. Dickey. 1990 . Irrigation for arid areas. p. 499-548. In G.J. Hoffman et al. (ed.). Management of farm irrigation systems. ASAE, St. Joseph, MI.
Carter, D.L. 1993. Furrow erosion lowers soil productivity. J. Irrig. Drain. Eng. ASCE. 119:964-974.

De Boodt, M.F., M.H.B. Hates, and A. Herbillon (ed.). 1990. Soil colloids and their associations in aggregates. NATO ASI Series B:Physics Vol.215. 598 p. Plenum Press, New York.

Gleick, P.H. 1993. An introduction to global fresh water issues. p. 3-12. In Water in crisis. Oxford Univ. Press, New York.

Hoffman, G.J., T.A. Howell and K.H. Solomon (ed.) 1990. Management of farm irrigation systems. ASAE, St. Joseph, MI.

Kay-Shoemake, J., and M. Watwood. 1996. Microbial ecology of polyacrylamide application in agricultural soils. p. 33-40. In R.E. Sojka and R.D. Lentz (ed.) Proc. Conf. on Managing Irrigation- Induced Erosion and Infiltration with Polyacrylamide, Twin Falls, ID. 6-8 May. Univ. of Idaho, Moscow.

Lentz, R.D. 1995. Irrigation (agriculture): Use of water-soluble polyacrylamide to control furrow-irrigation induced erosion p. 163-165. In S.P. Parker (ed.) Yearbook of science \& technology-1996, McGraw-Hill, Inc., New York.

Lentz, R.D., I. Shainberg, R.E. Sojka, and D.L. Carter. 1992. Preventing irrigation furrow erosion with small applications of polymers. Soil Sci. Soc. Am. J. 56:1926-1932.

Lentz, R.D., and R.E. Sojka. 1994. Field results using polyacrylamide to manage furrow erosion and infiltration. Soil Sci. 158:274-282.

Lentz, R.D., and R.E. Sojka. 1996. Polyacrylamide application to control furrow irrigation-induced erosion. p. 419-430. In Proc. 27th Annu. Int. Erosion Control Assoc. Conf., Seattle, WA. 27 Feb.-1 Mar. IECA, Steamboat Springs, CO.

Lentz, R.D., R.E. Sojka, and D.L. Carter. 1993. Influence of polymer charge type and density on polyacrylamide ameliorated irrigated furrow erosion. p. 159-168. In Proc. 24th Annu. Int. Erosion Control Assoc. Conf., Indianapolis, IN. 23-26 Feb. IECA, Steamboat Springs, CO.

Lentz, R.D., T.D. Steiber, and R.E. Sojka. 1995. Applying polyacrylamide (PAM) to reduce erosion and increase infiltration under furrow irrigation. p. 79-92. In L.D. Robertson et al. (ed.) Proc. Winter Commodity Schools-1995. Univ. of Idaho Coop. Ext.

Malik, M, A. Nadler, and J. Letey. 1991. Mobility of polyacrylamide and polysaccharide polymer through soil materials. Soil Technol. 4:255-263.

McCutchan, H., P. Osterli, and J. Letey. 1994. Polymers check furrow erosion, help river life. Calif. Agric. 47:10-11.

Mitchell, A.R. 1986. Polyacrylamide application in irrigation water to increase infiltration. Soil Sci. 141:353-358.

Quastel, J.H. 1954. Soil Conditioners. Annu. Rev. Plant Phys. 101. 5:75-92

Rangeley, W.R. 1987. Irrigation and drainage in the world. p. 29-35. In W.R. Jordan (ed.) Proc. Water and Water Policy in World Food Supplies Conf. Texas A \& M Univ. Press, College Station.

Ross, C.W., R.E. Sojka, R.D. Lentz. 1996. Polyacrylamide as a tool for controlling sediment runoff and improving infiltration under furrow irrigation. p. 229-230. In N. Uren (ed.) Proc. Aust. and N.Z. Natl. Soils Conf., Melbourne. 1-4 July.

Ross, M.A., and C.A. Lembi. 1985. Applied weed science. McMillan and Co., New York.

Singh, G., J. Letey, P. Hanson, P. Osterli, and W.F. Spencer. 1996. Soil erosion and pesticide transport from an irrigated field. J. Environ. Sci. Health B31(1):25-41.

Sojka, R.E. 1997. Research contribution to the understanding and management of irrigation-induced erosion. Chapter 2. In F.J. Pierce and W.W. Frye (ed.) Research contributions to 50 years of soil and water conservation in the United States. Soil and Water Conserv. Soc., Ankeny, IA (in press).

Sojka, R.E., and R.D. Lentz. 1994a. Net infiltration and soil erosion effects of a few ppm polyacrylamide in furrow irrigation water. p. 349-354. In H.B. So et al.(ed.) Proc. 2nd Int. Sym. on Sealing, crusting and hardsetting soils, Brisbane, Australia. 7-11 Feb. Univ. of Queensland, Brisbane, Australia.

Sojka, R.E., and R.D. Lentz. 1994b. Polyacrylamide (PAM): A new weapon in the fight against irrigation-induced erosion. USDA-ARS Soil and Water Manage. Res. Unit Station Note no. 01-94, Kimberly, ID.

Sojka, R.E., and R.D. Lentz. 1996a. Polyacrylamide for furrow-irrigation erosion control. Irrig. J. 46:8-11.

Sojka, R.E., and R.D. Lentz. 1996b. Off-standard application of Polyacrylamide for furrow erosion control. p. 287. In Agronomy abstracts. ASA, Madison, WI. 
Sojka, R.E., and R.D. Lentz (ed.) 1996c. p. 287. In Proc. Conf. on Managing Irrigation-Induced Erosion and Infiltration with Polyacrylamide, Twin Falls, ID. 6-8 May. Univ. of Idaho, Moscow.

Sojkg, R.E., R.D. Lentz, C.W. Ross, and T.J. Trout. 1996. Net and tension infiltration effects with PAM in furrow irrigation. p. 93-102. In R.E. Sojka and R.D. Lentz (ed.) Proc. Conf. on Managing Irrigation-Induced Erosion and Infiltration with Polyacrylamide, Twin Falls, ID. 6-8 May. Univ. of Idaho, Moscow.

Sojka, R.E., R.D. Lentz, and D.T. Westermann. 1995. Water and erosion management with PAM in furrow-irrigated potatoes. p. 284 , In Agronomy abstracts. ASA, Madison, WI.

Tribe, D. 1994. Feeding and greening the world, the role of agricultural research. CAB Int., Wallingford, Oxon, UK.
Trout, T.J. 1996. Furrow irrigation erosion and sedimentation: On-field distribution. Trans. ASAE 39(5):1717-1723.

Trout, T.J., R.E. Sojka, and R.D. Lentz. 1993. Polyacrylamide effect on furrow erosion and infiltration. ASAE paper 932032. ASAE, St. Joseph, MI.

Trout, T.J., R.E. Sojka, and R.D. Lentz. 1995. Polyacrylamide effect on furrow erosion and infiltration. Trans. ASAE. 38(3):761-765.

Wallace, A. 1986. Effect of polymers in solution culture on growth and mineral composition of tomatoes. Soil Sci. 141:395-396.

Wallace, A., G.A. Wallace, and A.M. Abouzamzam. 1986. Effects of excess levels of a polymer as a soil conditioner on yields and mineral nutrition of plants. Soil Sci. 141:377-380. 